\title{
ANÁLISE DE PERDAS DE INVESTIMENTOS EM LANÇAMENTO DE PRODUTO ALIMENTÍCIO
}

Anderson Cristyan Reis SILVA (Unileste); Gustavo Campos SILVA (Unileste); Elizabete Marinho Serra NEGRA (Unileste)

Introdução: $\mathrm{O}$ mercado está cada vez mais exigente tornando assim essencial para a competitividade das empresas desenvolverem novos produtos que reflitam na manutenção dos custos, na percepção de valor para os clientes e na qualidade. $\mathrm{O}$ processo de desenvolvimento de produtos demanda altos investimentos, planejar estes é essencial para que as empresas possam obter bons resultados, alcançar retorno sobre os investimentos. A contabilidade gerencial pode auxiliar nesse processo, avaliando ganhos e resultados financeiros. Neste contexto essa pesquisa tem o Objetivo de avaliar perdas em um investimento operacional e os fatores que influencia no resultado. Objetivo: Objetivo Geral

-Identificar e analisar as perdas de investimentos em lançamento de produto alimentício.

Específicos

-Levantar bibliografia sobre o tema

-Levantar os tipos e valores de investimentos

-Descrever os motivos da não aceitação do produto no mercado

- Verificar se a perda do investimento pode ser reversível.

Metodologia: A natureza desse trabalho se classifica como exploratória com estudo de caso, o tipo de abordagem utilizada foi de natureza mista..

É a abordagem onde é utilizado como pesquisa um contexto qualitativo e também quantitativo aonde de maneira objetiva o pesquisador desenvolve conceitos, ideias e entendimentos a partir de padrões encontrados nos dados, nessa abordagem o pesquisador é um interpretador da realidade (GIL, 2002).

O trabalho utilizou três técnicas de levantamento de dados, entrevista, questionário e documentos. Resultados: A comparação entre os dados demonstram que o produto embora haja receptividade do público, não há intenção de um uso constante, como é o caso dos suplementos alimentares e tampouco está correlacionado aos interesses e objetivos predominantes entre os respondentes.

Diversos fatores influenciam o resultado do consumo diário, a preocupação com o excesso de calorias e a falta de proteínas aparece como limitadores, visto que as motivações em praticar atividades físicas são antônimas a porções de componentes do produto. Conclusão: Analisando o processo de desenvolvimento de produtos e os investimentos que a empresa realizou, pode-se levantar que o objetivo de retorno da empresa não foi alcançado, apresentando um prejuízo acumulado $\mathrm{R} \$ 57.721,60$, sendo que $\mathrm{R} \$ 52.000,00$ é o valor do investimento realizado e $\mathrm{R} \$ 5.721,60$ de prejuízo acumulado.

Palavras-chave: Contabilidade gerencial. Retorno de investimentos. Novos produtos.

Agências de fomento: Unileste 